\title{
Pemanfaatan Nanokalsium Tulang Ikan Nila (Oreochromis niloticus) pada Beras Analog dari Berbagai Macam Ubi Jalar (Ipomoea batatas L.) Utilization of Tilapia (Oreochromis niloticus) Bone Nanocalcium into Artificial Rice from Various Sweet Potato (Ipomoea batatas L.)
}

Novia Anggraen*, Yudhomenggolo Sastro Darmanto, Putut Har Riyadi

Fakultas Perikanan dan IImu Kelautan, Jurusan Perikanan, Program Studi Teknologi Hasil Perikanan Universitas Diponegoro, Semarang

*Korespondensi dengan penulis (noviaanggraeni9@yahoo.com)

Artikel ini dikirim pada tanggal 24 Mei 2016 dan dinyatakan diterima tanggal 1 November 2016. Artikel ini juga dipublikasi secara online melalui www.jatp.ift.or.id. Hak cipta dilindungi undang-undang. Dilarang diperbanyak untuk tujuan komersial.

Diproduksi oleh Indonesian Food Technologists® @2016

\begin{abstract}
Abstrak
Perkembangan konsumsi masyarakat terhadap pangan semakin meningkat. Pengkayaan produk pangan menjadi poros utama yang harus dilakukan untuk mengatasi masalah penyediaan pangan yang memiliki kandungan gizi tinggi, menyehatkan, dan diterima konsumen. Ubi jalar merupakan salah satu sumber karbohidrat yang rendah kalori dan tulang ikan yang melimpah juga memiliki kandungan protein dan kalsium yang tinggi yang diperlukan oleh tubuh. Beras analog merupakan beras tiruan yang dapat mengatasi permasalahan kebutuhan beras nasional yang semakin menurun. Tujuan dari penelitian ini adalah untuk mengetahui pengaruh penambahan konsentrasi nanokalsium tulang ikan terhadap kandungan kalsium dan fosfor beras analog ubi jalar. Materi yang digunakan dalam penelitian ini adalah tulang ikan Nila (Oreochromis niloticus), ubi jalar (Ipomoea batatas L.) putih, kuning, dan ungu, dengan desain percobaan Rancangan Acak Lengkap (RAL) yang terdiri dari 3 perlakuan yang dilakukan dengan 3 kali pengulangan. Parameter pengujian yaitu uji SEM, PSA, proksimat, kalsium, fosfor, hedonik, dan indeks glikemik Data dianalisis menggunakan ANOVA, dilanjutkan dengan uji BNJ untuk menementukan beda nyata. Hasil penelitian menunjukkan bahwa perbedaan ubi jalar berpengaruh nyata $(P<0,05)$ terhadap kadar kalsium, fosfor, dan sensori. Beras analog ubi ungu dengan penambahan nanokalsium $5 \%$ memiliki hasil terbaik dari semua parameter, dengan IG (Indeks Glikemik) 19,19 (kategori rendah) dan BG (Beban Glikemik) 7,21 (kategori rendah).
\end{abstract}

Kata kunci: beras analog ,kalsium, indeks glikemik, tulang ikan, ubi jalar

\begin{abstract}
The development of domestic consumption on food is developing. The food enrichment becomes principal axis to be done to overcome the problem of food supply which has high nutritional ingredients, healthy, and broadly accepted by consumers. Sweet potato is one source of carbohydrates which has low calories. Fish bones contain high protein and calcium for the human consumption. Currently, the national rice supply decreases. Artificial rice is artificial rice that can overcome the problems of the national rice supply. The aim of this study were to determine the effect of fish bone nano calcium concentration into the calcium and phosphorus content of sweet potato analog rice. The material used in this study were tilapia (Oreochromis niloticus) bone, sweet potato (Ipomoea batatas L.) white, yellow, and purple, with completely randomized design with triplication. All samples were analysed for SEM, $P S A$, proximate calcium, phosphorus, sensory test, and index glycemic. Data were analyzed using ANOVA, followed by HSD test for determining a real difference. The results showed that the various sweet potato significantly affects $(P<0.05)$ into: calcium content, phosphorus content, and sensory test. The purple sweet potato analog rice with the addition of 5\% nanocalsium was the best results of all the parameters, with Glycemic Index of 19.19 (low category) and Glycemic Load of 7.21 (low category).
\end{abstract}

Keywords: artificial rice, calcium, fish bone, glycemic index, sweet potato

\section{Pendahuluan}

Produksi perikanan budidaya ikan nila mengalami peningkatan tiap tahunnya. Menurut data Kementrian Perikanan dan Kelautan (2014) pada tahun 2011, jumlah produksi ikan nila mencapai 22.534 ton dan pada tahun 2012 mencapai 27.386 ton. Menurut beberapa peneliti sebelumnya, produksi pengolahan ikan nila umumnya menghasilkan limbah mencapai $15 \%$, dengan kandungan mineral $60-70 \%$ dalam bentuk garam organik terutama kalsium fosfat, kreatin fosfat, dan hidroksiapatit yang berbentuk kristal yang melekat pada kolagen fibril dan kalsium tulang ikan berbentuk kompleks dengan fosfor yang merupakan mineral berbagai komponen metabolisme pada proses biokimia fisiologis dan pemeliharaan jaringan tulang.

Nanokalsium adalah kalsium yang dihasilkan dengan memanfaatkan teknologi nano sehingga sangat efisien dalam memasuki suhu tubuh karena ukuran yang super kecil mencapai $500 \times 10^{-9} \mathrm{~nm}$ sehingga dapat terabsorbsi secara cepat dan sempurna ke dalam tubuh dan menurut Mohanraj dan Chen (2006) Nanopartikel adalah partikel yang berukuran 10-1000 $\mathrm{nm}$. Nanokalsium memiliki biovaibilitas yang lebih tinggi dibandingkan kalsium yang berukuran makro, sehingga nanokalsium yang terbuang melalui urin lebih rendah. Menurut peneliti terdahulu aplikasi teknologi nano dalam bahan pangan meliputi peningkatan rasa, warna, flavour, tekstur, dan konsistensi produk pangan, serta 
meningkatkan penyerapan biovalidinitas nutrisi dan senyawa bioaktif. Nanokalsium dapat ditambahkan dalam produk makanan, salah satunya beras analog.

Beras analog merupakan sebutan lain dari beras tiruan (artificial rice). Beras analog disebut juga beras cerdas adalah beras yang dibuat dari bahan non padi dengan kandungan karbohidrat yang menyerupai beras pada umumnya. Pembuatan beras analog dilakukan dengan metode granulasi dan ekstruksi. Beberapa hal yang perlu diperhatikan dalam mutu rasa beras analog sebagai pengganti beras adalah tekstur, pengembangan volume, dan nilai gizi.

Salah satu bahan non padi yang dapat dimanfaatkan untuk pembuatan beras analog adalah ubi jalar. Nilai produksi ubi jalar di Indonesia pada tahun 2008 adalah 1.880.977 ton dengan luas panen sebesar $174,561 \mathrm{Ha}$ dan produktivitasnya mencapai 107,75Ku/Ha. Beberapa peneliti menyatakan bahwa ubi jalar merupakan tanaman dengan kandungan nutrisi yang tingggi yang kaya akan vitamin (B1, B2, C dan E), mineral (kalsium, potasium, magnesium, dan zinc), dietary fiber, dan karbohidrat. Oleh karena itu, perlu adanya alternatif untuk mencukupi kebutuhan beras di Indonesia, serta memiliki kandungan yang baik untuk kesehatan, yaitu dengan melakukan penelitian Pemanfaatan Nanokalsium Tulang Ikan Nila (Oreochromis niloticus) pada Beras Analog dari Berbagai Macam Ubi Jalar (Ipomoea batatas L).

\section{Materi dan Metode \\ Materi}

Bahan yang digunakan dalam penelitian ini adalah tepung ubi jalar ungu, ubi jalar kuning, dan ubi jalar putih yang diproses di UKM Putri 21 Gunungkidul, Jogjakarta. Tulang ikan nila (O. niloticus) merupakan bahan baku pembuatan nanokalsium diperoleh dari PT Aquafarm, Semarang. GMS (Gliserol monostearat) diperoleh dari Laboratorium Fateta IPB, Bogor. Peralatan yang digunakan selama penelitian adalah baskom, ekstruder, mixer "Philips", blender kering "Panasonic MXJ1G", water bath, oven "Memmert".

\section{Metode}

Penelitian berlangsung selama periode September- Januari 2016. Penelitian meliputi proses pembuatan nanokalsium dan pembuatan beras analog. Analisis yang dilakukan adalah fisikokimia nanokalsium meliputi rendemen nanokalsium yang dihasilkan, analisa proksimat, kalsium, ukuran partikel (PSA), morfologi dan komponen nanokalsium (SEM-EDS). Sedangkan analisis pada beras analog meliputi kadar kalsium, fosfor, hedonik, dan Indeks Glikemik.

\section{Proses Pembuatan Nanokalsium}

Proses pembuatan nanokalsium diawali dengan proses ektraksi tepung tulang ikan nila menggunakan metode basa yang dikembangkan oleh Lekahena et al. (2014) dengan modifikasi. Bubuk kasar tulang ikan nila diekstraksi dengan $\mathrm{NaOH} 1 \mathrm{~N}$ dengan suhu $100^{\circ} \mathrm{C}$. Hasil ekstraksi selanjutnya dilakukan pendinginan, filltrasi dan netralisasi. Setelah hasil ekstraksi netral, selanjutnya dilakukan proses pengeringan dengan suhu $50^{\circ} \mathrm{C}$ hingga menjadi serbuk putih halus yang disebut nanokalsium.

\section{Proses Pembuatan Beras Analog}

Proses pembuatan beras analog diawali dengan proses penepungan bahan baku dengan hammer mill yang dikembangkan oleh Mishra et al. (2012) dengan modifikasi. Tepung ubi jalar putih, kuning, dan ungu dimasukkan kedalam baskom dengan menambahkan nanokalsium dengan konsentrasi yang berbeda yaitu $5 \%, 10 \%$, dan $15 \%$. Proses selanjutnya menambahkan air sebanyak 30\% dan GMS 2\% untuk mempermudah proses pengadonan. Langkah terakhir yaitu proses ekstruksi dengan suhu $70^{\circ} \mathrm{C}$ untuk menghasilkan bulir beras yang sempurna.

Tabel 1. Komposisi Kimia Nanokalsium

\begin{tabular}{lc}
\hline Parameter & Nanokalsium Tulang Ikan Nila (Oreochromis niloticus) \\
\hline Rendemen (\%) & 5,84 \\
Ukuran Partikel (nm) & 729,69 \\
Air (\%) & $3,52 \pm 0,17$ \\
Abu (\%) & $78,82 \pm 1,23$ \\
Protein (\%) & $0,21 \pm 0,02$ \\
Lemak (\%) & $1,21 \pm 0,10$ \\
Kalsium (\%) & $19,27 \pm 0,53$ \\
Fosfor (\%) & $8,65 \pm 0,50$ \\
\hline
\end{tabular}

Tabel 2. Hasil Penilaian Hedonik Beras Analog Nanokalsium dengan Perbedaan Ubi Jalar

\begin{tabular}{cccc}
\hline \multicolumn{3}{c}{ Beras analog nanokalsium } \\
\hline Parameter & Putih & Kuning & Ungu \\
\hline Warna & $2,07 \pm 0,83^{\mathrm{a}}$ & $2,63 \pm 1,03^{\mathrm{b}}$ & $4,50 \pm 0,57^{\mathrm{C}}$ \\
Aroma & $2,13 \pm 0,68^{\mathrm{a}}$ & $2,87 \pm 0,82^{\mathrm{b}}$ & $4,47 \pm 0,63^{\mathrm{c}}$ \\
Kelengketan & $1,77 \pm 0,63^{\mathrm{a}}$ & $2,77 \pm 0,92^{\mathrm{b}}$ & $4,77 \pm 0,55^{\mathrm{c}}$ \\
Rasa & $1,70 \pm 0,75^{\mathrm{a}}$ & $2,53 \pm 0,94^{\mathrm{b}}$ & $4,57 \pm 0,57^{\mathrm{C}}$ \\
Selang & $0,81<\mu<2,03$ & $1,92 \leq \mu \leq 3,42$ & $4,52 \leq \mu \leq 4,58$ \\
Kepercayaan & $2,33 \pm 0,48$ & $3,07 \pm 0,64$ & $4,70 \pm 0,47$ \\
Overall & & &
\end{tabular}


Tabel 3. Pengujian Proksimat Nasi Analog

\begin{tabular}{ccc}
\hline No & Analisa & Nasi analog ungu dengan nanokalsium $5 \%$ \\
\hline 1. & Kadar air $(\% b b)$ & $52,65 \pm 0,13$ \\
2. & Kadar abu $(\% b b)$ & $2,15 \pm 0,01$ \\
3. & Kadar protein $(\% b b)$ & $7,41 \pm 0,02$ \\
4. & Kadar lemak (\%bb) & $0,20 \pm 0,01$ \\
5. & Kadar karbohidrat by diff & $37,59 \pm 0,17$ \\
6. & Cooking time(menit) & $4,78 \pm 0,015$ \\
\hline
\end{tabular}

Tabel 4. Indeks Glikemik dan Beban Glikemik Nasi Analog Ubi Jalar Ungu

\begin{tabular}{cccccc}
\hline Sampel & Indeks Glikemik & Kategori IG & $\begin{array}{c}\text { Karbohidrat/s } \\
\text { aji (g) }\end{array}$ & Beban Glikemik & Kategori BG \\
\hline $\begin{array}{c}\text { Nasi analog ubi } \\
\text { ungu }\end{array}$ & $19,19 \pm 14,05$ & Rendah & 37,59 & 7,21 & Rendah \\
\hline
\end{tabular}

\section{Analisis Statistik}

Data yang diperoleh, dianalisis dengan metode One-Way ANOVA menggunakan SPSS 16.0 Statistic Software. Level signifikan sebesar $a=0,05$.

\section{Hasil dan Pembahasan}

Komposisi Kimia Nanokalsium

Komposisi kimia nanokalsium tersaji pada Tabel 1. Hasil penelitian menunjukkan bahwa rendemen nanokalsium sebesar 5,84\%. Rendemen yang dihasilkan lebih rendah dibandingkan dengan hasil penelitian (Lekahena et al., 2014) yang menyatakan bahwa rendemen nanokalsium tulang ikan nila dengan ekstraksi basa sebesar 5,91\% dan dengan ekstraksi asam sebesar 4,41\%. Hal ini disebabkan oleh perbedaan lama waktu ekstraksi karena semakin lama waktu ekstraksi, maka rendemen yang dihasilkan semakin bertambah hingga terjadi kesetimbangan konsentrasi dalam larutan atau titik jenuh. Penelitian Brojer et al. (2002) menyebutkan bahwa semakin lama waktu ekstraksi maka rendemen yang dihasilkan semakin tinggi, karena kesempatan kontak antara bahan dan pelarut semakin besar, namun apabila waktu ekstraksi terlalu lama, rendemen akan menurun kemungkinan karena larutan sudah mencapai titik jenuh. Rendemen adalah persentase bahan baku utama (tulang ikan) yang diproses menjadi produk akhir (nanokalsium).

Analisis ukuran partikel nanokalsium menggunakan SEM (Scanning Electron Microscopy) dan PSA (Particle Size Analyzer). Hasil pengukuran partikel dengan menggunakan SEM pada perbesaran 500x sampai $10.000 x$ menunjukkan bahwa ukuran partikel serbuk nanokalsium yang dihasilkan berkisar 500-1000 nm. Menurut Mohanraj dan Chen (2006) nanopartikel didefinisikan sebagai partikel yang berukuran kisaran 10-1000 nm. Komponen nanokalsium dapat diketahui melalui analisa EDS. Berdasarkan hasil analisa EDS, nanokalsium terdiri dari massa karbon sebanyak $20,23 \%$, oksigen $20 \%$, fosfor $28 \%$, dan kalsium 32\%. Morfologi dan komponen nanokalsium tersaji pada Figur 1. Berdasarkan hasil pengujian dengan PSA (Particle Size Analyzer), diperoleh ukuran rerata ukuran partikel sebesar 729,69 $\mathrm{nm}$. Hasil yang didapatkan dari penelitian ini sudah berukuran nanopartikel karena ukurannya masih dibawah $1000 \mathrm{~nm}$. Nanopartikel adalah partikel yang berukuran 10-1000 nm (Mohanraj dan Chen, 2006).
Ukuran partikel pada penelitian ini masih berukuran lebih besar dibandingkan hasil penelitian Lekahena et al. (2014) yang menghasilkan nanokalsium dengan ukuran partikel 235,93 $\mathrm{nm}$. Hal tersebut dikarenakan tidak dilakukan proses penggilingan serbuk menggunakan milling. Sintesis nano material dapat dilakukan secara top down. Top down merupakan pembuatan struktur nano dengan memperkecil ukuran material dengan proses penggilingan menggunakan milling. Distribusi ukuran partikel menggunakan PSA (Particle Size Analyzer) dapat dilihat pada Figur 2.
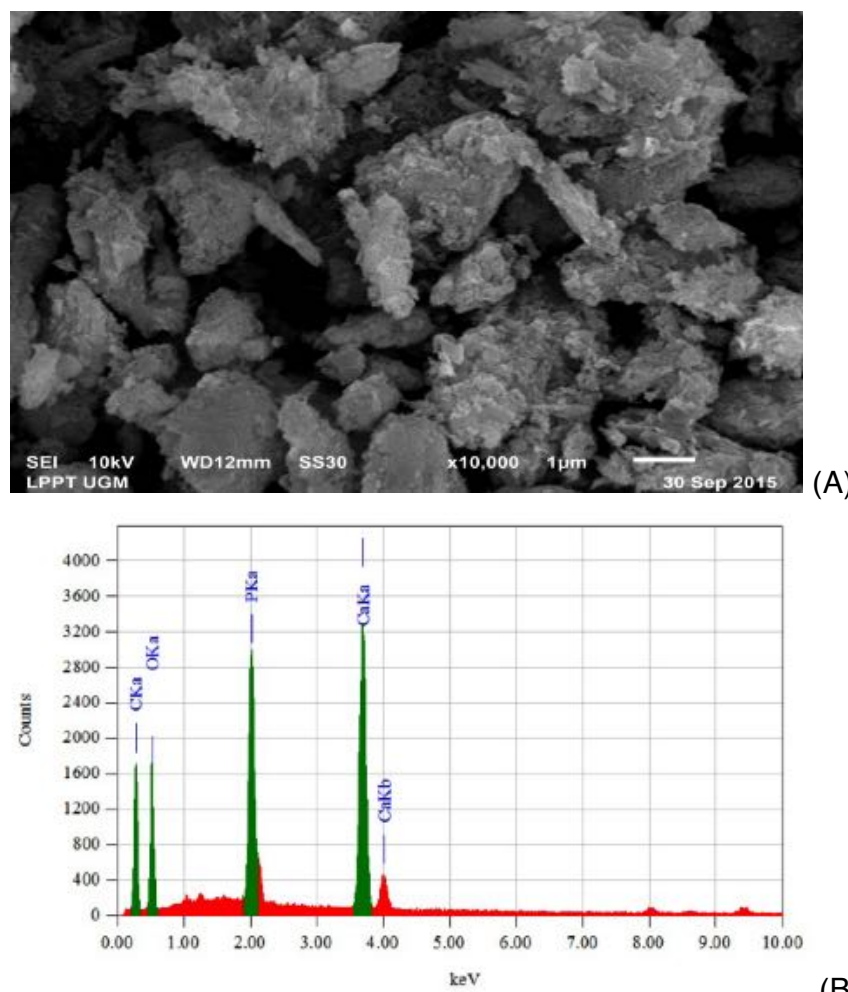

Figur 1. Morfologi dan Komponen Nanokalsium (A) Hasil Scanning Electron Microscopy Nanokalsium Perbesaran 10.000x, dan (B) Elektron Dispersi.

Hasil penelitian menunjukkan kadar abu nanokalsium yang dihasilkan sebesar 78,82 \%. Kadar abu yang tinggi disebabkan oleh kandungan mineral yang ada pada nanokalsium. Kadar abu pada penelitian Lekahena et al. (2014) sebesar 85,44\% jauh lebih tinggi dibandingkan nanokalsium pada penelitian ini. Hal ini disebabkan lebih tingginya kandungan mineral pada nanokalsium tersebut. Menurut Ferazumma et al. 
(2011) kandungan abu pada bahan pangan dipengaruhi oleh jumlah mineral yang ada didalamnya. Salah satu contoh dari mineral adalah kalsium.

Kadar protein nanokalsium dengan metode basa yang dilakukan pada penelitian ini sebesar $0,21 \%$ lebih rendah dibandingkan kandungan nanokalsium dengan metode asam pada penelitian Lekahena et al. (2014) yaitu $7,03 \%$. Hal ini disebabkan oleh adanya perbedaan metode ekstraksi asam dan basa. Menurut Ferazumma (2011) kadar protein tepung tulang ikan dengan hidrolisis basa $(\mathrm{NaOH})$ lebih rendah karena diduga $\mathrm{NaOH}$ dapat menghidrolisis protein dalam tulang ikan. Menurut Wardani et al. (2012) menjelaskan bahwa untuk meningkatkan kadar kalsium pada tepung tulang tuna diperlukan pemisahan protein dengan kalsium melalui proses deproteinase. Hal ini dapat dibuktikan pada perlakuan autoklaf selama 1 jam, kadar kalsium tepung tulang tuna semakin meningkat seiring menurunnya kadar protein.

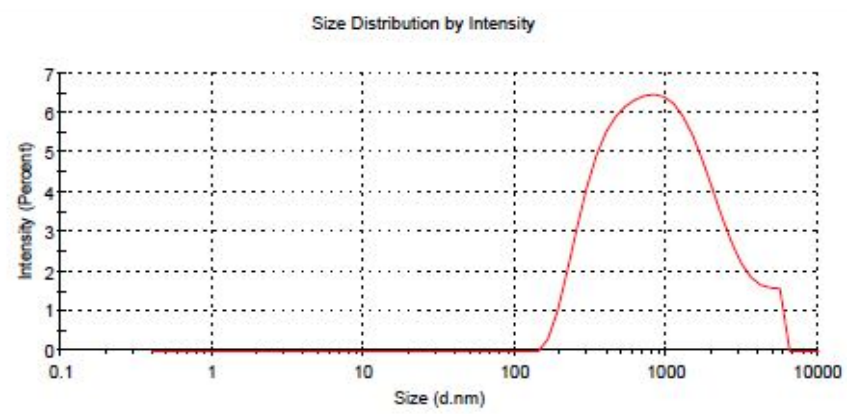

Figur 2. Distribusi Ukuran Partikel menggunakan PSA (Particle Size Analyzer).

Kadar air nanokalsium tulang ikan nila sebesar $3,52 \%$, dengan metode ekstraksi basa, sedangkan menurut ISA (International Seafood of Alaska) kandungan air pada tepung tulang ikan yaitu $3,6 \%$ dan menurut hasil penelitian Lekahena et al. (2014) kandungan kadar air nanokalsium yaitu sebesar 4,34\%. Perbedaan kadar air pada nanokalsium dipengaruhi oleh cara pengeringan yang berbeda. Penelitian ini menggunakan pemanasan oven dengan suhu $70^{\circ} \mathrm{C}$ saat pembuatan nanokalsium, yang berbeda dengan penelitian Lekahena et al. (2014) yaitu menggunakan sinar matahari. Menurut Rachmawan (2001) pengeringan menggunakan oven akan menghasilkan suhu yang stabil dan lebih tinggi dibandingkan dengan sinar matahari. Semakin tinggi suhu dan kecepatan aliran udara pengeringan, semakin cepat pula pengeringan berlangsung, sehingga dapat menghasilkan kadar air yang lebih rendah.

Kadar kalsium dan fosfor pada penelitian ini sebesar $19,27 \%$ dan $8,65 \%$, dengan rasio perbandingan 2,2:1. Berbeda dengan kadar kalsium dan fosfor pada penelitian Lekahena et al. (2014) yaitu pada nanokalsium ekstraksi asam $21,48 \%$ dan $11,78 \%$. Perbedaan kadar kalsium dan fosfor ini disebabkan oleh perlakuan ekstraksi yang berbeda. Perlakuan ekstraksi yang berbeda menggunakan asam dan basa mengakibatkan terhidrolisisnya protein dan lemak yang terdapat pada matriks tulang, sehingga meningkatkan kadar kalsium dan fosfor pada sampel.

\section{Kadar Kalsium Beras Analog}

Hasil dari analisa keragaman didapatkan hasil bahwa perbedaan tepung ubi jalar berpengaruh nyata terhadap nilai kadar kalsium beras analog. Perbedaan antar perlakuan diakibatkan karena perbedaan bahan baku pada beras analog. Nilai kadar kalsium terendah terdapat pada beras analog ubi jalar kuning yaitu sebesar $0,350 \%$ dan tertinggi pada beras analog ubi ungu yaitu $0,880 \%$. Kandungan tertinggi kalsium terdapat pada beras analog ubi jalar ungu dikarenakan ubi jalar ungu memiliki kadar kalsium tertinggi jika dibandingkan dengan ubi jalar putih, dan kuning. Kandungan kalsium ubi jalar ungu, putih, dan kuning menurut peneliti sebelumnya adalah $57 \mathrm{mg}, 30 \mathrm{mg}$, dan $30 \mathrm{mg} / 100$ gram bahan segar. Pengaruh perbedaan jenis ubi jalar terhadap nilai kadar kalsium beras analog tersaji pada Figur 3.

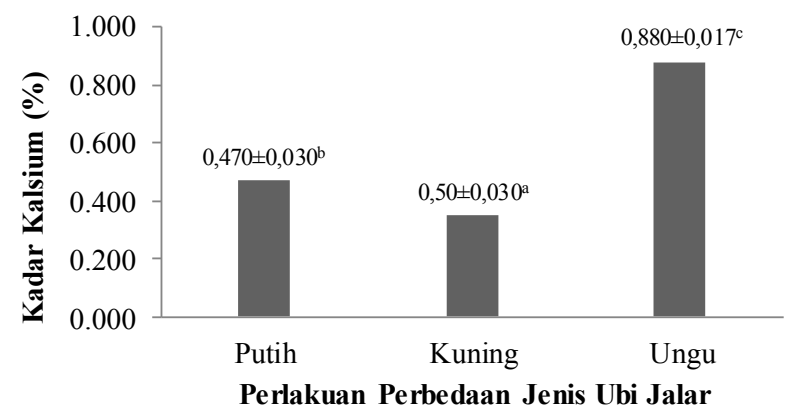

Figur 3. Pengaruh Perbedaan Jenis Ubi Jalar terhadap Nilai Kadar Kalsium Beras Analog. Data Merupakan Hasil rata-rata dari tiga kali ulangan \pm standar deviasi. Huruf superscript yang berbeda menyatakan setiap perlakuan berbeda nyata $(\mathrm{P}<0,05)$. Keterangan: putih adalah beras analog ubi jalar putih, kuning adalah beras analog ubi jalar kuning, ungu adalah beras analog ubi jalar ungu.

Berdasarkan hasil pengujian diperoleh kadar kalisum beras analog dari penambahan nanokalsium $5 \%$, diperoleh kadar kalsium sebesar $0,880 \%$ atau $880 / 100 \mathrm{~g}$ takaran saji nasi perhari. Kadar kalsium ini sesuai dengan AKG (Angka Kebutuhan Gizi) Kalsium menurut Kemenkes (2014) yang menyatakan bahwa anak-anak pada usia 4-6 tahun memerlukan kalsium $1000 \mathrm{mg} / \mathrm{hari}$. Menurut Winarno (2004) tubuh kita mengandung lebih banyak kalsium dari pada mineral lainnya, diperkirakan sekitar $2 \%$ berat badan orang dewasa atau sekitar 1,0-1,4 kg. Jumlah ini, 99\% berada dalam jaringan keras, yaitu tulang dan gigi. Kebutuhan kalsium dalam tubuh manusia per hari untuk anak-anak dan orang dewasa sangat berbeda. Orang dewasa memerlukan kalsium per hari 800-1000 mg/hari dan anak-anak 500-700 mg/hari, maka dapat disimpulkan bahwa penambahan nanokalsium pada komposisi beras analog dapat dijadikan salah satu alternatif untuk perbaikan kadar kalsium pada produk, dan peningkatan nilai tambah pada tulang ikan.

Hasil kadar kalsium pada penelitian ini lebih tinggi jika dibandingkan dengan kadar kalsium penelitian Permana et al. (2012) tentang fortifikasi 
tepung cangkang udang kedalam cone ice cream pada konsentrasi $5 \%$ dengan kadar kalsium 1,24\% dan lebih tinggi jika dibandingkan dengan penelitian yang dilakukan oleh Justicia et al. (2012) tentang fortifikasi tepung tulang nila merah kedalam roti tawar pada konsentrasi $5 \%$ menghasilkan kadar kalsium 0,476\%. Konsumsi kalsium per hari hendaknya tidak lebih dari 2500 mg. Menurut Almatsier (2004) kelebihan kalsium dapat menimbulkan batu ginjal dan gangguan ginjal. Selain itu dapat menyebabkan konstipasi (susah buang air besar). Kalsium yang terdapat pada beras analog cukup untuk memenuhi kebutuhan harian kalsium hal ini dikarenakan penyerapan kalsium dipengaruhi umur dan kondisi tubuh. Menurut Winarno (2004) pada usia anak-anak atau masa pertumbuhan, sekitar $50 \%-70 \%$ kalsium yang dicerna diserap. Tetapi pada usia dewasa, hanya sekitar $10-40 \%$ yang mampu diserap tubuh. Penyerapan kalsium terjadi pada usus kecil bagian atas, tepat setelah lambung. Penyerapan kalsium dapat dihambat apabila ada zat organik yang dapat bergabung dengan kalsium dan membentuk garam yang tidak larut.

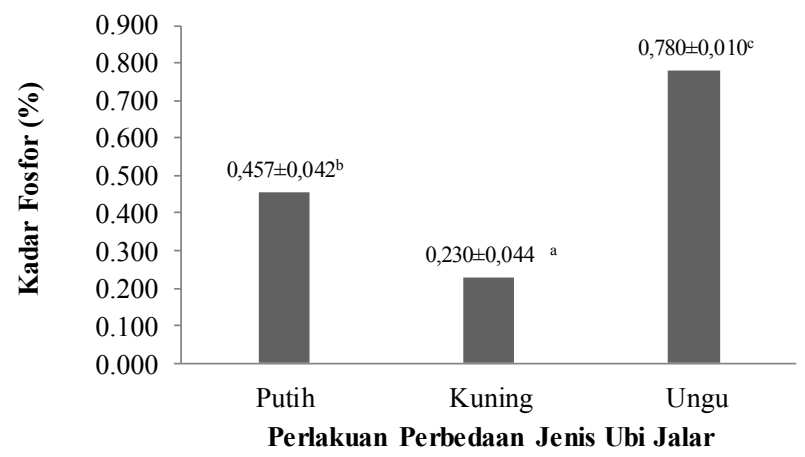

Figur 4. Pengaruh Perbedaan Jenis Ubi Jalar terhadap Nilai Kadar Fosfor Beras Analog. Data Merupakan Hasil Rata-Rata dari Tiga Kali Ulangan \pm Standar Deviasi. Huruf Superscript yang Berbeda Menyatakan Setiap Perlakuan Berbeda Nyata $(\mathrm{P}<0,05)$. Keterangan: putih adalah beras analog ubi jalar putih, kuning adalah beras analog ubi jalar kuning, ungu adalah beras analog ubi jalar ungu.

\section{Kadar Fosfor Beras Analog}

Kadar fosfor tertinggi yaitu pada beras analog ubi ungu, dengan kadar fosfor sebesar $0,780 \%$. Menurut Basmal et al. (2000) perbandingan antara kalsium dan fosfor pada tulang adalah 2:1. Perbandingan antara kalsium dan fosfor 1:1 sampai 3:1 pada proses penyerapan kalsium didalam rongga usus merupakan perbandingan yang terbaik. Perbandingan kalsium dan fosfor yang lebih besar dari 3:1 akan menimbulkan penyakit desiensi kalsium yaitu rakhitis. Hasil pengujian fosfor pada penelitian ini lebih rendah dibandingkan hasil penelitian Indrasari (2006) yang menunjukkan bahwa beras komersial IR64 mempunyai kandungan fosfor sebesar $3500 \mathrm{ppm}$ atau setara dengan 3,5\%. Namun, menurut Kemenkes (2014) angka kecukupan gizi pada fosfor maksimal $1200 \mathrm{mg}$. Pengaruh perbedaan jenis ubi jalar terhadap nilai kadar fosfor beras analog tersaji pada Figur 4 .
Hedonik Beras Analog

Uji hedonik dilakukan untuk membandingkan tampilan fisik dan rasa pada beras analog yang telah dibuat dengan parameter yaitu kenampakan, bau, rasa dan tekstur pada beras analog. Beras analog yang diuji hedonik yaitu beras analog dengan perlakuan ubi jalar putih, kuning dan ungu. Hasil penilaian uji hedonik beras analog nanokalsium dengan perbedaan ubi jalar dapat dilihat pada Tabel 2.

\section{Warna}

Hasil uji kenampakan pada perlakuan beras analog menggunakan Kruskal Wallis diperoleh nilai Chisquare hitung $(55,679)>$ nilai Chi-square tabel $5 \%$ $(5,991)$, sehingga disimpulkan perbedaan penambahan tepung ubi jalar memberikan pengaruh berbeda nyata terhadap kenampakan beras analog. Hasil uji hedonik parameter kenampakan beras analog didapatkan nilai tertinggi yaitu 4,50 pada perlakuan ubi jalar ungu. Beras analog dengan perlakuan ubi jalar putih mempunyai nilai terendah yaitu 2,07. Hal ini diduga karena penambahan tepung ubi jalar putih, kuning, dan ungu memberikan pengaruh terhadap beras analog sehingga kenampakan beras analog yang dihasilkan memberikan warna yang disuka oleh konsumen. Menurut Saputra et al. (2014) konsumen akan lebih menyukai produk dengan bentuk yang rapi, bagus dan utuh dibandingkan dengan produk yang kurang rapi dan tidak utuh. Warna merupakan atribut yang pertama kali diterima oleh indera manusia dan perbedaan warna meskipun sedikit memberikan efek yang berbeda terhadap penerimaan setiap individu.

Warna ungu pada beras analog ubi ungu disebabkan oleh kandungan antosianin. Menurut Leighton et al. (2010) kandungan antosianin pada ubi jalar juga berpotensi sebagai bahan pewarna alami untuk makanan ataupun minuman. Stabilitas warna antosianin terhadap pengaruh panas dan sinar UV lebih tinggi pada ubi jalar ungu dibandingkan antosianin yang berasal dari strawberry, raspberry, apel dan kedelai hitam. Antosianin adalah metabolit sekunder dari famili flavonoid, dalam jumlah besar ditemukan dalam buahbuahan dan sayur-sayuran. Antosianin adalah suatu kelas dari senyawa flavonoid, yang secara luas terbagi dalam polifenol tumbuhan. Berdasarkan beberapa peneliti antosianin pada ubi jalar ungu memiliki perbedaan aktivitas antioksidan yang terletak pda jenis zat warna. Ubi jalar kuning ditemukan dominan adalah jenis pelargonidim-3-rutinoside-5-glucoside, sedangkan pada ubi jalar ungu adalah antosianin dan peonidin glikosida yang mempunyai aktivitas dan zat warna lebih kuat.

\section{Aroma}

Hasil uji aroma pada perlakuan beras analog menggunakan Kruskal Wallis diperoleh nilai Chi-square hitung $(59,440)>$ nilai Chi-square tabel 5\% $(5,991)$, sehingga disimpulkan perbedaan ubi jalar memberikan pengaruh berbeda nyata terhadap bau beras analog. Hasil uji hedonik parameter aroma beras analog didapatkan nilai tertinggi yaitu 4,47 pada perlakuan ubi 
jalar ungu dan terendah ubi jalar putih yaitu 2,13 yang memberikan pengaruh berbeda nyata antar perlakuan. $\mathrm{Hal}$ ini diduga karena perbedaan tepung ubi jalar mempengaruhi bau pada beras analog, sehingga bau yang dihasilkan dari setiap perlakuan tidak memberikan bau yang berbeda. Menurut Suwikatmono et al. (2013) perbedaan ubi jalar terhadap bihun berpengaruh terhadap aroma yang dihasilkan. Berdasarkan penelitian Leksrisompong et al. (2012) aroma terbaik pada uji hedonik aneka ubi jalar terdapat pada ubi jalar ungu.

Penambahan tepung ubi jalar putih, kuning, dan ungu berpengaruh terhadap bau beras analog. Hal ini disebabkan oleh bau dari tepung ubi jalar ungu memiliki bau yang lebih wangi. Menurut Winarno (2004) aroma makanan dalam banyak hal dapat menentukan enak atau tidaknya makanan, bahkan lebih kompleks dari pada rasa dan kepekaan indera pembauan yang biasanya lebih tinggi dari indera pencicipan bahkan industri pangan menganggap sangat penting terhadap uji bau karena dapat dengan cepat memeberikan hasil penilaian apakah produk disukai atau tidak. Aroma makanan juga salah satu indikator penting dalam menentukan kualitas bahan pangan untuk menentukan kelezatan bahan makanan tersebut. Umumnya konsumen akan menyukai bahan pangan jika mempunyai aroma khas yang tidak menyimpang dari aroma normal.

\section{Kelengketan}

Hasil uji kelengketan pada perlakuan beras analog menggunakan Kruskal Wallis diperoleh nilai Chisquare hitung $(65,355)>$ nilai Chi-square tabel $5 \%$ $(5,991)$, sehingga disimpulkan perbedaan ubi jalar memberikan pengaruh berbeda nyata terhadap kelengketan beras analog. Hasil uji hedonik parameter kelengketan beras analog, didapatkan nilai tertinggi yaitu 4,77 pada perlakuan ubi jalar ungu dan ubi jalar putih mempunyai nilai terendah yaitu 1,77. Hal ini disebabkan oleh kandungan protein dalam beras analog ubi jalar ungu cukup tinggi. Sifat fungsional protein menentukan atribut hedonik produk pangan yang dihasilkan. Menurut Pratiwi et al. (2012) karakteristik fungsional protein dari bahan pangan berpengaruh terhadap kualitas suatu produk pangan.

Karakteristik fungsional apabila mengalami proses pengolahan akan menentukan atribut produk pangan seperti tekstur, hedonik dan nutrisi. Sebagian besar sifat fungsional antara lain akan berpengaruh pada kualitas tekstur bahan pangan dan memegang peranan penting dalam analisa sifat fisik bahan pangan selama proses pengolahan. Proses pemanasan dalam ekstruder merupakan proses yang dapat berpengaruh pada sifat fungsional protein. Tekstur merupakan salah satu parameter yang penting dalam penerimaan nasi, yang meliputi kepulenan dan kelengketan. Beras analog ubi jalar ungu memiliki kelengketan yang paling disukai dengan karakteristik tidak terlalu lunak dan pera, dengan kata lain beras analog ubi jalar ungu memiliki kepulenan menyerupai beras biasa seperti beras IR 36. Menurut Moretti et al. (2006) kepulenan dan kelengketan nasi sebagian besar dipengaruhi oleh kadar amilosa dan amilopektin.

\section{Rasa}

Hasil uji rasa pada perlakuan beras analog menggunakan Kruskal Wallis diperoleh nilai Chi-square hitung $(63,456)$ > nilai Chi-square tabel 5\% $(5,991)$, sehingga disimpulkan perbedaan tepung ubi jalar memberikan pengaruh berbeda nyata terhadap rasa beras analog. Hasil uji hedonik parameter rasa beras analog didapatkan nilai tertinggi yaitu 8,3 pada perlakuan ubi jalar ungu dan ubi jalar putih mempunyai nilai terendah yaitu 7,67. Hal ini diduga karena perbedaan ubi jalar memberikan pengaruh terhadap rasa beras analog sehingga rasa yang dihasilkan pada beras analog menjadi lebih disukai oleh konsumen. Menurut Suryaningrum et al. (2002) cita rasa makanan dipengaruhi oleh komponen-komponen yang terdapat di dalam makanan seperti protein, lemak, dan karbohidrat yang menyusunnya. Uji rasa lebih banyak melibatkan indera lidah yang dapat diketahui melalui kelarutan bahan makanan dalam kontak dengan syaraf perasa.

\section{Nilai Indeks dan Beban Glikemik Beras Analog}

Berdasarkan hasil pengujian kalsium, fosfor, dan hedonik yang telah dilakukan, didapatkan produk terpilih yaitu perlakuan penambahan nanokalsium 5\% pada ubi ungu. Jumlah relawan yang memenuhi syarat sebagai subjek pengukuran indeks glikemik sebanyak 20 orang yang terdiri atas 7 orang laki-laki dan 13 orang wanita. Tidak dilakukan perbandingan yang seimbang antara jumlah relawan laki-laki dan perempuan. Hal tersebut dikarenakan relawan laki-laki banyak yang merasa tidak sanggup memenuhi persyaratan yang diwajibkan antara lain berpuasa dan diambil darahnya. Menurut Rimbawan dan Siagian (2004) perbedaan antara jumlah laki-laki dan wanita tidak terlalu berpengaruh signifikan terhadap hasil pengujian nilai indeks glikemik produk, sehingga memungkinkan adanya ketidaksamaan jumlah subjek laki-laki dan perempuan. Dari data 20 orang tersebut kemudian diseleksi dan didapatkan 10 data yang ditampilkan pada penelitian ini. Penggunaan data 10 orang dikarenakan adanya beberapa data yang bias. Data bias antara lain dikarenakan nilai kurva melebihi kurva standar maupun hasil perhitungan data sampel yang terlalu rendah dibandingkan dengan data standar.

\section{Karakteristik Sampel Uji Indeks Glikemik}

Analisa proksimat nasi analog digunakan untuk perhitungan kesetaraan karbohidrat (berdasarkan karbohidrat by difference) pada analisis indeks glikemik. Pengujian proksimat nasi analog tersaji pada Tabel 3. Hasil ini menunjukkan bahwa kadar karbohidrat by different dari beras analog ubi ungu dengan perlakuan penambahan nanokalsium $5 \%$ adalah $37,59 \pm 0,17$. Beras analog ubi ungu dengan perlakuan nanokalsium $5 \%$ menggunakan perbandingan air dan beras sebesar $1,8: 1$. Perbandingan beras dan air diperoleh dari terlihatnya nasi yang sudah matang tidak memiliki 
butiran tepung lagi. Jika perbandingan air kurang dari yang ditentukan, maka nasi yang dihasilkan akan memiliki tekstur bertepung dan menimbulkan nilai hedonik yang rendah saat dimakan karena terasa belum matang dan keras.

Jumlah sampel nasi yang akan dikonsumsi oleh relawan, dari beras analog ubi ungu dengan perlakuan penambahan nanokalsium $5 \%$ sebanyak $66,51 \mathrm{~g}$. Jumlah tersebut didapat dari kesetaraan $25 \mathrm{~g}$ karbohidrat pangan acuan dan karbohidrat sampel masing-masing nasi. Menurut Ranawana et al. (2009) penggunaan kesetaraan $25 \mathrm{~g}$ karbohidrat bertujuan untuk mengurangi bias yang terjadi saat pengonsumsian sampel. Hal ini dikarenakan faktor hedonik nasi beras analog yang kurang manis seperti nasi pada umumnya saat dikonsumsi, sehingga dapat menyebabkan relawan merasa mual saat mengkonsumsi nasi analog.

Penelitian ini menggunakan pangan acuan berupa roti tawar. Alasan penggunaan roti tawar adalah IG yang sama dengan IG glukosa murni yaitu 100 . Menurut Mssallem et al. (2011) pangan acuan lain yang dapat digunakan adalah roti tawar. Alasannya roti tawar lebih mencerminkan mekanisme fisiologis dan metabolisme daripada glukosa murni. Hal ini selaras dengan penelitian yang dilakukan oleh Gutiérrez et al. (2012) bahwa untuk mendapatkan respon indeks glikemik dapat menggunakan roti tawar sebagai pangan kontrol karna memiliki IG yang sama dengan glukosa murni.

\section{Indeks dan Beban Glikemik Nasi Analog Terpilih}

Pengambilan darah relawan dilakukan melalui pembuluh darah kapiler yang terdapat di ujung jari tangan. Hal ini dikarenakan darah yang diambil dari pembuluh darah ini memiliki variasi kadar glukosa darah yang lebih kecil dibandingkan darah yang diambil dari pembuluh vena. Glukosa darah yang diambil bereaksi dengan enzim glucose oxydase (GOD) dan potassium ferricyanide yang terdapat pada test strip pengujian. Reaksi tersebut menghasilkan potrassium ferrocyanide. Jumlah potrassium ferrocyanide yang dihasilkan setara dengan jumlah glukosa yang terkandung pada sampel (Raben, 2014). Data indeks glikemik yang disajikan adalah data indeks glikemik rata-rata 10 orang dari 20 orang subjek yang berpartisipasi. Indeks glikemik dan beban glikemik nasi analog ubi jalar ungu tersaji pada Tabel 4. Penyajian data 10 subjek dari total 20 subjek dikarenakan banyaknya bias data. Bias data tersebut adalah glukosa darah yang tidak stabil pada rentang waktu pengujian, terlalu tinggi ataupun terlalu rendah. Selain itu adanya subjek relawan yang menghasilkan nilai indeks glikemik yang terlalu besar dibandingkan relawan lainnya (data pencilan/ outliner). Berdasarkan penelitian Thompson et al. (2012) relawan yang diperlukan pada pengujian indeks glikemik pada kacang dan beras sejumlah 17 orang dengan 9 laki-laki dan 8 perempuan, namun hanya diambil 10 relawan terbaik.

Indeks glikemik nasi analog ubi jalar ungu tergolong kedalam IG kategori rendah $(<55)$. Menurut
Venn et.al. (2014) bahwa mengkonsumsi pangan IG rendah mampu memperbaiki sensitivitas insulin, menurunkan laju penyerapan glukosa, serta bermanfaat dalam pengendalian glukosa darah sehingga dapat menurunkan risiko komplikasi pada penderita diabetes melitus tipe 2. Beban glikemik beras analog ubi jalar ungu dengan penambahan nanokalsium $5 \%$ yaitu 7,21 (termasuk kategori BG rendah). Pada perhitungan BG, digunakan jumlah sajian untuk beras analog perlakuan penambahan nanokalsium sebanyak $100 \mathrm{~g}$. Berdasarkan peneliti sebelumnya bahwa jumlah sajian untuk nasi putih dan nasi merah di Indonesia umumnya sebesar $150 \mathrm{~g}$. Beban glikemik beras analog menunjukkan bahwa konsumsi nasi analog sejumlah $100 \mathrm{~g}$ dengan jumlah karbohidrat per saji sebesar 66,51 g lambat untuk meningkatkan kadar glukosa darah. Hal ini dipengaruhi pula dengan IG nasi analog nanokalsium 5\% yang termasuk pada kategori rendah.

Berdasarkan hasil pengambilan gula darah, indeks glikemik nasi analog ubi jalar ungu dengan penambahan nanokalsium 5\% adalah 19,19 $\pm 14,05$. Penelitian Arif et al. (2013) menunjukkan bahwa beras IR 36 memiliki IG (Indeks Glikemik) sebesar 45. IG (Indeks Glikemik) beras IR 36 lebih tinggi jika dibandingkan IG beras analog ubi jalar ungu. Hal ini disebabkan oleh perbedaan kadar lemak dan protein. Berdasarkan penelitian Purwani et al. (2007) menunjukkan bahwa beras IR 36 memiliki kadar protein sebesar $7,39 \%$ dan kadar lemak sebesar 0,19\%. Menurut Widanagamage et al. (2009) kandungan protein dan lemak dapat mempengaruhi tinggi rendahnya IG (Indeks Glikemik). Semakin tinggi kadar protein dan lemak maka semakin rendah nilai IG (Indeks Glikemik). Kurva perubahan gula darah ditampilkan pada

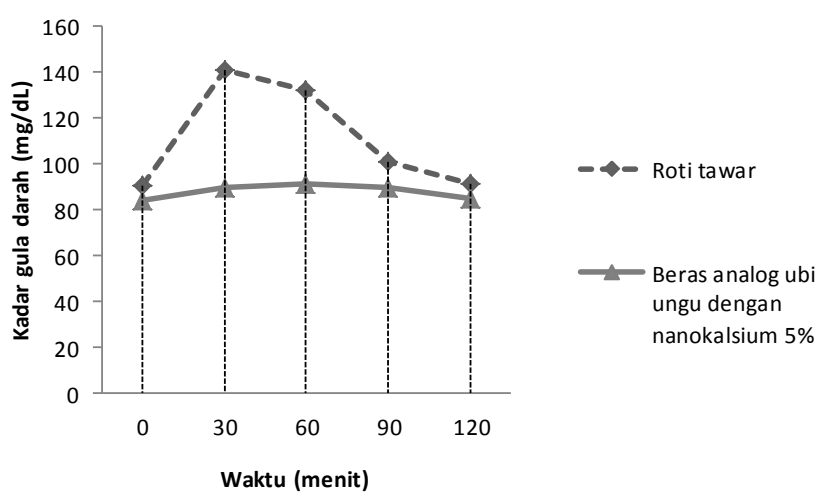

Figur 5 Kurva Perubahan Kadar Gula Darah

Faktor lain yang mempengaruhi IG (Indeks Glikemik) penelitian ini adalah kandungan kalsium. Semakin tinggi kalsium maka cooking time dan suhu gelatinisasi akan semakin rendah. Hal ini didukung oleh penelitian Ribeiro et al. (2014) beras dengan merek Xamego memiliki kadar kalsium tertinggi sebesar $1,64 \%$ menghasilkan cooking time terendah yaitu 17 menit. Menurut Truong et al. (2014) bahwa tinggi rendahnya Indeks Glikemik dapat dipengaruhi juga oleh cooking time dan suhu gelatinisasi. Hal ini diperkuat 
pula oleh Wariyah et al. (2014) yang menyatakan bahwa beras Ciherang dan IR 42 yang diberikan perlakuan penambahan kalsium memiliki suhu gelatinisasi terendah yaitu $80^{\circ} \mathrm{C}$ dengan cooking time 10 menit. Penelitian Purwani et al. (2007) menunjukkan bahwa beras IR 36 memiiki suhu gelatinisasi paling rendah yaitu $81^{\circ} \mathrm{C}$ menghasilkan IG (Indeks Glikemik) dengan kategori rendah sebesar 45 .

\section{Kesimpulan}

Berdasarkan hasil penelitian yang diperoleh penambahan nanokalsium tulang ikan nila (Oreochromis niloticus) dengan konsentrasi 5\% berpengaruh terhadap kadar kalsium dan fosfor pada ubi jalar putih, kuning, dan ungu. Uji BNJ pada kadar kalsium dan fosfor beras analog menunjukkan bahwa terdapat perbedaan yang nyata $(p<0,05)$ pada semua perlakuan yaitu kuning-ungu, putih- ungu, dan putihkuning. Kadar kalsium dan fosfor tertinggi terdapat pada beras analog ubi jalar ungu yaitu masing-masing $0,88 \%$ dan $0,78 \%$. Hasil penerimaan para konsumen menunjukkan bahwa beras analog ubi jalar ungu paling disukai oleh konsumen dengan kriteria yaitu warna, aroma, kelengketan dan rasa. Berdasarkan analisa hedonik terdapat perbedaan sangat nyata pada perlakuan ubi jalar putih terhadap ubi jalar kuning, ubi jalar putih terhadap ubi jalar ungu, dan ubi jalar kuning terhadap ubi jalar ungu. Ubi jalar terbaik pada penelitian ini adalah ubi jalar ungu karena memiliki nilai hedonik, fosfor, dan kalsium tertinggi. Beras analog ubi jalar ungu memiliki nilai indeks glikemik 19,19 (kategori rendah) dan beban glikemik 7,21 (kategori rendah).

\section{Ucapan Terima Kasih}

Penelitian ini disponsori oleh PT Indofood Sukses Makmur Tbk dalam kerangka Program Indofood Riset Nugraha 2015/2016

\section{Daftar Pustaka}

Almatsier S. 2004. Prinsip Dasar Imu Gizi. Gramedia Pustaka Utama. Jakarta.

AOAC. 2007. Official Methods of Analysis of The Association of Official Analytical Chemist. Inc., Washington, DC.

Arif, Abdullah., Agus, Budiyanto., dan Hoerudin. 2013. Nilai indeks glikemik produk pangan dan faktorfaktor yang memengaruhinya. Jurnal Litbang Pertanian. 32 (3): 91-99.

Brojer, J., Stamfli, H., and Graham, T. 2002. Effect of extraction time and acid concentration on the separation of proglycogen and macroglycogen in horse muscle samples. Canadian Journal of Veterinary Reasearch 66(3):201-206.

Ferazumma, H., Sri, A. M., Amalia, dan Leily, A. 2011. Subsitusi tepung kepala ikan lele dumbo (clarias gariepinus) untuk meningkatkan kandungan kalsium crackers. Jurnal Gizi dan Pangan 6 (1):18-27.

Gutiérrez, Ruiz., Q. Ramos., M. Pizarro., T. Abbud., Barnard., M. Meléndez1., And L. Gutiérre. 2012. Nixtamalization in Two Steps with Different
Calcium Salts and The Relationship with Chemical, Texture and Thermal Properties in Masa and Tortilla. Journal of Food Process Engineering.35 (2012):772-783.

Justicia, H.A., Hamdani., dan E. Liviawaty. 2012. Fortifikasi tepung tulang nila merah sebagai sumber kalsium terhadap tingkat kesukaan roti tawar. Jurnal Perikanan dan Kelautan 3 (4):1727.

Indrasari, Siti. 2006. Kandungan mineral padi varietas unggul dan kaitannya dengan kesehatan. Jurnal Iptek Tanaman Pangan 1 (1): 88-99.

Kementrian Kelautan dan Perikanan. 2014. Data Ekspor Ikan Nila.http://. kkp.go.id. (diakses pada: 1 November 2015).

Kementrian Kesehatan Republik Indonesia. 2012."Perilaku Cerdik Mencegah Osteoporosis".http://www.depkes.go.id. (diakses pada: 1 November 2015).2014.Angka Kecukupan Gizi. http://www.depkes.go.id. (diakses pada: 1 November 2015).

Leighton, C.S., Schoenfeldt., And Kruger. 2010. Quantitative descriptive sensory analysis of five different cultivars of sweetpotato to determine sensory and textural profiles. J. Sensory Studies 25: 2-18.

Lekahena, V., D. N. Faridah., R. Syarief, dan R. Peranginangin. 2014. Karakterisasi fisikokimia nanokalsium hasil ekstraksi tulang ikan nila menggunakan larutan basa dan asam. Jurnal Teknologi dan Industri Pangan. 25(1): 57-64.

Leksrisompong, P., Whitson., Truong., and Drake. 2012. Sensory attributes and consumer acceptance of sweet potato cultivars with varying flesh colors. Journal of Sensory Studies Issn 0887-8250

Mishra, A., Mishra, H.N., and Rao, P.S. 2012. Preparation of rice analogues using extrusion technology. Int. J. Food Sci. Tech 47: 17891797.

Mohanraj VJ, Chen Y. 2006. Nanoparticels-a review. Trop J Pharm Res 5: 561-573.

Moretii, D., Michael, B.Z., Sumithra, M., Prashanth, T., Tung-Ching L., Anura RK, and Richard FH. 2006. Extruded rice fortified with micronized ground ferric pyrophosphate reduces iron defi ciency in indian schoolchildren: a double-blind randomized controlled the american. Journal of Clinical Nutrition 84: 822-829.

Mssallem, Al., H. Frost., and JE Brown. 2011. A study of hassawi rice (Oryza Sativa $L$ ) in terms of its carbohydrate hydrolysis (in vitro) and glycaemic and insulinaemic indices (in vivo). European Journal of Clinical Nutrition 65: 627-634.

Permana, Azhari., E. Liviawaty., dan Inskandar. 2012. Fortifikasi tepung cangkang udang sumber kalsium terhadap tingkat kesukaan cone es krim. Jurnal Perikanan dan Kelautan 3 (4): 29-39.

Pratiwi, A. R., Hartayanie, L., dan Tabita, A. 2012. Sifat fungsional protein spirulina platensis. Jurnal Teknologi Pangan. Universitas Katolik 
Soegijapranata. Semarang.

Purwani, E. Y., Yuliani, S., Indrasari, S. D., Nugraha, S., dan Thahir, R. 2007. Sifat fisikokimia beras dan indeks glikemiknya. Jurnal Teknologi dan Industri Pangan 18(1).

Raben, Anne. 2014. Glycemic Index and Metabolic Risks: How Strong Is The Evidence? Am J Clin Nutr 100:1-3

Rachmawan, O. 2001. Pengeringan, Pendinginan, dan Pengemasan Komoditi Pertanian. Buletin Departemen Pendidikan. Jakarta

Ranawana, V., Leow., and Henry. 2014. Mastication Effects on the glycaemic index: impact on variability and practical implications. European Journal of Clinical Nutrition 68:137-139.

Regina. 2012. Daftar indeks glikemik makanan. Pusat Informasi tentang Penyakit Diabetes (Internet). (diunduh 20 Agustus 2015). Tersedia pada: http://diabetesmelitus.org.

Ribeiro, Nerineira., J. Rodrigues., M. Prigol., C. Wayne., and L. Storck. 2014. Evaluation of special grains bean lines for grain yield, cooking time and mineral concentrations. Crop Breeding and Applied Biotechnology 14: 15-22.

Rimbawan dan A. Siagian. 2004. Indeks Glikemik Pangan.Penebar Swadaya. Jakarta.

Saputra, J. S. E., A. Tri Winarni., dan E. Nurcahyadewi. 2014. Pengaruh penambahan biomassa serbuk spirulina platensis terhadap sifat fisik, kimia dan sensori pada tablet hisap (Lonzenges). JPHPI.17(3).

Suryaningrum, D. T., Murdinah., dan Arifin, M. 2002. Penggunaan kappa-karaginan sebagai bahan penstabil pada pembuatan fish meat loaf dari ikan tongkol (Euthynnus pelamys. L). Jurnal
Penelitian Perikanan Indonesia (Edisi Pasca Panen) 8 (6).

Suwikatmono, Adi., G. Himawan., dan J. Kato. 2013. Modifikasi fisik tepung ubi jalar dan aplikasinya dalam pengembangan produk bihun. Jurnal Penelitian dan Pengembangan Pertanian 30(5): 120-130.

Thompson, Sharon., D. Winham., and A. M Hutchins .2012. Bean and rice meals reduce postprandial glycemic response in adults with type 2 diabetes: a cross-over study. Nutrition Journal 11(23).

Truong, V.D., Wei, Cheng Yuet, and Micki D. Hall. 2014. Glycemic index of american-grown jasmine rice classified as high. Int J Food Sci Nutr 65 (4): 436-439.

Venn, Bernard., M. Kataoka, and J. Mann. 2014. The use of different reference foods in determining the glycemic index of starchy and non-starchy test foods. Nutrition Journal 13.

Wardani, Dini., E. Liviawaty., dan Junianto. 2012. Fortifikasi tepung tulang ikan tuna sebagai sumber kalsium terhadap tingkat kesukaan donat. Jurnal Perikanan dan Kelautan 3 (4): 4150.

Wariyah, C., A. Astuti, M., and Supriyadi. 2014. Pasting properties of calcium-fortified rice. International Food Research Journal 21(3): 989-993

Widanagamage, Rahal., S. Ekanayake., and J. Welihinda. 2009. Carbohydrate-rich foods: glycaemic indices and the effect of constituent macronutrients. International Journal of Food Sciences and Nutrition 60: 215-223.

Winarno, F.G. 2004. Kimia Pangan dan Gizi. PT Gramedia. Jakarta. 